\section{DIGITAL COMMONS \\ @ UNIVERSITY OF SOUTH FLORIDA}

\section{Revista Surco Sur}

Volume 10 | Issue 13

Article 8

$9-8-2020$

\title{
Las Voces
}

José María Vitier

Follow this and additional works at: https://digitalcommons.usf.edu/surcosur

\section{Recommended Citation}

Vitier, José María. 2020. Las Voces. Revista Surco Sur, Vol. 10: Iss. 13, 12.

DOI: http://dx.doi.org/10.5038/2157-5231.10.13.6

Available at: https://digitalcommons.usf.edu/surcosur/vol10/iss13/8

This HONRAR, HONRA is brought to you for free and open access by the Open Access Journals at Digital Commons @ University of South Florida. It has been accepted for inclusion in Revista Surco Sur by an authorized editor of Digital Commons @ University of South Florida. For more information, please contact digitalcommons@usf.edu. 


\section{Dossier dedicado a Eliseo Diego en su centenario}

José María Vitier

\section{Las Voces}

\section{Eliseo Diego*}

La voz de Eliseo, grave, indisoluble de aquella su ansiosa respiración, aquellas pausas, de fumador impenitente que tenían en Eliseo la misma solemnidad (y un significado equivalente) al silencio; ese jadeante silencio que competía con su palabra hablada y hacía brotar en su voz los versos como al final de la incurable fatiga de un combate; voz de lector, también, de humeante conversador. Lenta y llena de su propio eco como de un secreto que uno podía compartir solo al hablar con él.

Recuerdo también su otra voz, conspiradora, cómplice, como de actor secundario, que alguna tarde me contó directamente a mí, sin testigos, sus sigilosas andanzas más secretas. Respeto esos secretos. Ahora me quedo con la voz de sus poemas, la de su mejor papel, que era él mismo, actuando o jugando a ser él mismo, como si las cosas más serias de este mundo, todo ese saber contenido "entre la dicha y la penumbra" de su poesía, tuvieran el sesgo de una ancestral travesura.

Creo que nadie llevó su propia voz tan adentro en su escritura como Eliseo. Leerlo es oírlo. Pienso que su mejor voz, la que sigue sonando en mi corazón, es, seguramente, aquella misma voz con que vibraban sus versos perfectos dentro de su propia cabeza noble y taciturna.

* Fragmento dedicado a Eliseo Diego dentro del cuaderno “Las Voces” (aún inédito) 